\title{
PENENTUAN KADAR Cu, Fe, Zn DALAM TANAH, TANAMAN TEH, DAUN TEH DAN MINUMAN TEH
}

\author{
Supriyanto, Zainul Kamal \\ P3TM BATAN Yogyakarta
}

\begin{abstract}
ABSTRAK
PENENTUAN KADAR Cu, Fe, Zn DALAM TANAH, TANAMAN TEH, DAUN TEH DAN MINUMAN TEH. Salah satu penyebab kerusakan kualitas tanah adalah terjadinya pencemaran $\mathrm{Cu} F e$ danZn sehingga langsung maupun tidak langsung dapat menimbulkan pencemaran tanaman yang tumbuh diatasnya antara lain tanaman teh yang selama ini digunakan masyarakat secara luas sebagai bahan pembuatan minuman teh. Pengambilan sampel tanah, akar tanaman teh, daun teh, dan minuman teh dilakukan pada bulan Juni 2005 di kecamatan Keparakan, Temanggung, Jawa Tengah. Tujuan dari penelitian ini adalah untuk mengetahui kadar $\mathrm{Cu}$ Fe dan Zn di dalam tanah, akar tanaman teh, daun teh serta minuman teh. Penelitian dilakukan dengan cara sampel didigesti dengan asam nitrat pekat sampai diperoleh larutan yang jernih kemudian diencerkan dengan akuabides sampai $10 \mathrm{ml}$. Penentuan kadar unsur $\mathrm{Cu}, \mathrm{Fe}$, dan Zn menggunakan alat AAS. Diperoleh hasil kadar rata rata $\mathrm{Cu} F e$ dan $\mathrm{Zn}$ di dalamtanah dalam 0,155 $\pm 0,005$ ppm, 127,16 $\pm 2,65$ ppm, dan 0,68 $\pm 0,02$ ppm, di dalam tanah luar $0,355 \pm 0,025$ ppm, $360,59 \pm 13,17$ ppm dan 0,78 $\pm 0.01 \mathrm{ppm}$, di dalam akar tanaman teh $0,241 \pm 0,098 \mathrm{ppm}, 13,16 \pm 1,34 \mathrm{ppm}$ dan $2,64 \pm 0,06 \mathrm{ppm}$, di dalam daun teh $0,211 \pm 0,013 \mathrm{ppm}, 3,35 \pm 0,886 \mathrm{ppm}$, dan 0,795 $\pm 0,016 \mathrm{ppm}$ serta di dalam minuman teh 0,142 $\pm 0,086 \mathrm{ppm}, 6,11 \pm$ $0,35 \mathrm{ppm}$ dan $0,66 \pm 0,02 \mathrm{ppm}$
\end{abstract}

\section{ABSTRACT}

DETERMINATION OF CU, Fe, Zn ELEMENTS IN SOIL, ROOT TEA PLANTS, TEA LEAVES, ANDTEABEVERAGE. One of the causes of land quality damage was due to the pollution of $\mathrm{Cu}$, $\mathrm{Fe}$, and $\mathrm{Zn}$ so that it could directly and also indirectly cause the occurrance of pollution of plants which is growing on ifforexample tea plant that has been used by society for making of tea beverage. The sampling of soil, root tea plants, tea leaves and tea beverage samples were done in June, 2005 at subdistrict of Keparakan, Temanggung, Central Java. The purpose of research was to determine the content of $\mathrm{Cu}, \mathrm{Fe}$ and $\mathrm{Zn}$ in soil, root tea plants, tea leaves and tea beverage. The research was done by digesting the sample with nitric acid until the clear solution was obtained, then it was added by aquabidest until $10.0 \mathrm{ml}$. Determination of $\mathrm{Cu}, \mathrm{Fe}$ and $\mathrm{Zn}$ content used AAS instrument. The average concentration of $\mathrm{Cu} F e$ and $\mathrm{Zn}$ obtained in deep soil samples are $0.155 \pm 0.005 \mathrm{ppm}, 127.16 \pm 2.65 \mathrm{ppm}$, and $0.68 \pm 0.02 \mathrm{ppm}$ respectively, in surface soil samples are $0.355 \pm 0.025 \mathrm{ppm}, 360.59 \pm 13.17 \mathrm{ppm}$ and $0.78 \pm 0.01 \mathrm{ppm}$ respectively, in root of tea plants samples are $0.241 \pm 0.098 \mathrm{ppm}, 13.16 \pm 1.34 \mathrm{ppm}$ and $2.64 \pm 0.06 \mathrm{ppm}$ respectively, in tea leaves are $0.211 \pm 0.013 \mathrm{ppm}, 3.35$ $\pm 0.886 \mathrm{ppm}$, and $0.795 \pm 0.016 \mathrm{ppm}$ respectively and in tea beverage $0.142 \pm 0.086 \mathrm{ppm}, 6.11 \pm 0.35 \mathrm{ppm}$ and 0.66 \pm 0.02 ppm respectively.

\section{PENDAHULUAN}

T ingkungan yang bersih merupakan indikasi keberhasilan program pemerintah dalam pembangunan bidang

kesehatan yaitu tercapainya derajad kesehatan masyarakat yang optimal. Apabila lingkungan hidup tersebut mengalami kerusakan ataupun pencemaran maka akan menjadi tekanan yang paling berat terhadap kelangsungan makhluk hidup. Permasalahan lingkungan tidak akan terlepas dari dampak negatif yang terjadi akibat kemajuan industri yaitu terjadinya pencemaran lingkungan yang diakibatkan penanganan limbah industri yang kurang sempurna, meskipun pemerintah telah menerapkan berbagai peraturan pemerintah (PP) yang berkaitan dengan permasalahan pencemaran lingkungan. Salah satu bahan berbahaya dan toksis yang ada dalam limbah industri adalah logam berat seperti kadmium merkuri, arsen, tembaga, besi, seng dan yang lainnya. Logam berat pada umumnya bersifat racun terhadap makhluk hidup, walaupun beberapa di antaranya diperlukan dalam jumlah kecil. Di dalam tubuh manusia maupun hewan, logam berat akan terikat pada protein pengikat logam, misalnya 
metalotionin, sistein, dan haemoglobin. Protein tersebut akan mentransfer logam berat ke organ-organ tubuh sehingga akan terjadi akumulasi logam berat pada organ tubuh tertentu ${ }^{(1,2)}$.

Pencemaran logam berat seperti tembaga $(\mathrm{Cu})$, besi $(\mathrm{Fe})$ dan seng $(\mathrm{Zn})$ yang berasal dari limbah industri dapat terjadi melalui beberapa media seperti udara, tanah, tanaman, air maupun makanan. Tanah sebagai media tempat tumbuhnya tanaman dapat tercemar pula oleh logam berat, dan kandungan logam berat di dalam tanah sangat berpengaruh terhadap kandungan logam dalam tanaman yang tumbuh di atasnya sehingga kandungan logam yang kurang atau berlebihan dalam jaringan tanaman mencerminkan kandungan logam di dalam $\operatorname{tanah}^{(3)}$.

Selain tanah, perairanpun mempunyai peranan penting bagi kehidupan dan kesehatan manusia, baik digunakan untuk sumber air minum, keperluan sehari-hari maupun untuk mengairi lahan pertanian. Pencemaran akibat limbah industri yang mengandung logam berbahaya pestisida dan lainnya cenderung meningkatkan kasus keracunan dan gangguan kesehatan masyarakat. Pencemaran-pencemaran di atas sangat mempengaruhi kualitas tanaman yang berada pada daerah sekitarnya, dan logam berat tersebut akan terdistribusi ke tanah menuju tanaman dan akhirnya masuk ke tubuh manusia karena mengkonsumsi tanaman tersebut ${ }^{(4)}$.

Logam berat masuk ke dalam tubuh manusia biasanya melalui mulut yaitu makanan / minuman yang terkontaminasi oleh wadah (kaleng) atau lainnya dan juga melalui pernapasan seperti asap pabrik, proses industri. Kontaminasi makanan juga dapat terjadi dari tanaman pangan yaitu pada bidang pertanian dan perkebunan, dan akan menyebabkan toksisitas pada tubuh manusia jika jumlah logam berat pada tanaman melebihi atau lebih tinggi dibandingkan dengan standar mutu yang ditetapkan oleh Direktur Jendral Pengawasan Obat dan Makanan. Dari uraian di atas perlu diadakan penelitian untuk mengetahui berapa kadar logam dalam tanah tempat tumbuh tanaman, di dalam tanaman, dan produk yang dihasilkan dari tanaman tersebut, dengan demikian tujuan penelitian adalah untuk mengetahui kadar logam $\mathrm{Cu}, \mathrm{Fe}, \mathrm{Zn}$ dalam tanah, tanaman teh, daun teh dan minuman teh.

\section{BAHAN DAN TATA KERJA}

\section{Bahan dan alat}

Bahan yang digunakan adalah sampel tanah, akar tanaman teh, daun teh, dan minuman teh masing-masing diperoleh dari daerah kecamatan Keparakan, Temanggung Jawa Tengah, pengambilan sampel dilakukan pada bulan Juni 2005. Bahan yang lain adalah larutan spektrosol $\mathrm{Cu}$, Fe dan $\mathrm{Zn}$ buatan BDH, asam nitrat pekat, masing-masing buatan Merck dan Akuatrides buatan Lab. Kimia Analitik PTAPB-BATAN Yogyakarta.

Alat yang digunakan seperangkat alat spektrofotometer serapan atom model AA 300P buatan Techtron, Australia, alat-alat gelas seperti labu $5 \mathrm{ml}$, gelas beker $10 \mathrm{ml}$, pipet effendorf ukuran $50-250 \mu \mathrm{L}$ dan $100-1000$ $\mu \mathrm{L}$, teflon bomb digester.

\section{Tata kerja}

\section{Preparasi awal dan pelarutan sampel}

Sampel tanah hasil sampling dikeringkan di atas wadah (baki), pada temperatur kamar, dibersihkan dari kotoran, kerikil, dan daun-daun kering. Hasil pengeringan digerus menggunakan agat, kemudian disaring hingga lolos 100 mesh dan dihomogenkan, ditimbang $1 \mathrm{gr}$ sampel tanah yang telah homogen, dimasukkan dalam teflon bom digester, tambahkan $1 \mathrm{ml}$ asam nitrat pekat, tutup rapat dan dipanaskan dalam tungku pemanas pada suhu $150{ }^{\circ} \mathrm{C}$ selama 4 jam. Hasil pelarutan setelah dingin ditepatkan menjadi $10 \mathrm{ml}$ dengan menambahkan akuatrides sampai batas tanda.

Sampel akar tanaman teh, dan daun teh hasil sampling dibersihkan dari kotoran, dipotong kecil-kecil kemudian, masing-masing sampel dimasukkan ke dalam pengering suhu rendah selama 4 jam. Hasil pengeringan ditumbuk menggunakan alu stainless steel, diayak hingga lolos 100 mesh dan dihomogenkan. Proses pelarutan menggunakan teflon bom digester dilakukan dengan cara kerja yang sama seperti pada sampel tanah. 
Preparasi sampel minuman teh dilakukan dengan memanaskan sampel dalam gelas beker $10 \mathrm{ml}$ ditambahkan $1 \mathrm{ml}$ asam nitrat pekat di atas kompor pemanas. Hasil pemanasan setelah dingin ditepatkan menjadi $10 \mathrm{ml}$ dengan menambahkan akuatrides sampai batas tanda.

\section{Analisis $\mathrm{Cu}, \mathrm{Fe}$ dan $\mathrm{Zn}$ dalam sampel}

Analisis $\mathrm{Cu}, \mathrm{Fe}$ dan $\mathrm{Zn}$ dalam sampel tanah, akar tanaman teh, daun teh dan minuman teh dilakukan dengan teknik kurva kalibrasi standar yaitu dengan mengukur serapan unsur $\mathrm{Cu}$, Fe dan $\mathrm{Zn}$ pada kondisi optimum analisis masing-masing unsur. Serapan yang diperoleh kemudian diinterpolasikan ke dalam kurva kalibrasi masing-masing unsur, sehingga akan diperoleh kadar masing-masing unsur.

\section{HASIL DAN PEMBAHASAN}

Kadar $\mathrm{Cu}$, Fe dan $\mathrm{Zn}$ dapat ditentukan dengan memasukkan serapan sampel ke dalam persamaan regresi dan selanjutnya dilakukan perhitungan kadar sebenarnya yang hasilnya disajikan dalam Tabel 1.

Tabel 1. Kadar $\mathrm{Cu}$, $\mathrm{Fe}$, dan $\mathrm{Zn}$ di dalam tanah, akar tanaman teh, daun teh dan minuman teh

\begin{tabular}{|l|l|c|c|c|}
\hline \multirow{2}{*}{ No } & \multirow{2}{*}{ Jenis sampel } & \multicolumn{3}{|c|}{ Kadar Unsur $(\mathbf{p p m})$} \\
\cline { 3 - 5 } & & $\mathbf{C u}$ & $\mathbf{F e}$ & $\mathbf{Z n}$ \\
\hline \hline 1. & Tanah dalam & $0,155 \pm 0,005$ & $127,16 \pm 2,65$ & $0,68 \pm 0,02$ \\
\hline 2. & Tanah luar & $0,355 \pm 0,025$ & $360,59 \pm 13,17$ & $0,78 \pm 0,01$ \\
\hline 3. & Akar teh & $0,241 \pm 0,098$ & $13,16 \pm 1,34$ & $2,64 \pm 0,06$ \\
\hline 4. & Daun teh & $0,211 \pm 0,013$ & $3,35 \pm 0,886$ & $0,795 \pm 0,016$ \\
\hline 5. & Minuman teh & $0,142 \pm 0,086$ & $6,11 \pm 0,35$ & $0,66 \pm 0,02$ \\
\hline
\end{tabular}

Berdasarkan Tabel 1, ternyata pada masing-masing jenis sampel yaitu tanah dalam, tanah luar, akar dan daun teh serta minuman teh terdapat kadar $\mathrm{Cu}$, Fe dan $\mathrm{Zn}$ yang berbeda-beda. Kadar $\mathrm{Cu}$ pada tanah dalam 0,155 $\pm 0,005 \mathrm{ppm}$, pada tanah luar 0,355 $\pm 0,025 \mathrm{ppm}$, pada akar 0,241 $\pm 0,098 \mathrm{ppm}$, pada daun teh $0,211 \pm 0,013$ ppm dan pada minuman teh $0,142 \pm 0,086 \mathrm{ppm}$. Berdasarkan data tersebut terlihat bahwa kadar Cu pada tanah luar paling tinggi, dan kadar Cu pada tanah dalam paling rendah.

Sedangkan kadar Fe pada tanah dalam 127,16 $\pm 2,65$ ppm, pada tanah luar $360,59 \pm 13,17$ ppm, pada akar $13,16 \pm 1,34 \mathrm{ppm}$, pada daun teh $3.35 \pm 0.886 \mathrm{ppm}$ dan pada minuman teh $6,11 \pm 0,35 \mathrm{ppm}$. Di sini terlihat bahwa kadar Fe tertinggi terdapat pada tanah luar dan kadar terendah pada daun teh.

Besarnya kadar Fe yang ada pada minuman teh dibandingkan dengan yang ada dalam daun teh dapat terjadi karena pada saat pembuatan/penyeduhan minuman teh menggunakan air panas, terjadi pelarutan logam $\mathrm{Fe}$ yang semula terikat dalam daun teh ke dalam air seduhan.

Kadar Zn pada tanah dalam 0,68 $\pm 0,02 \mathrm{ppm}$, pada tanah luar 0,78 $\pm 0.01 \mathrm{ppm}$, pada akar 2,64 $\pm 0,06 \mathrm{ppm}$, pada daun teh $0,795 \pm 0,016 \mathrm{ppm}$ dan pada minuman teh terdapat kadar Zn sebesar 0,66 $\pm 0,02 \mathrm{ppm}$, terlihat bahwa kadar Zn tertinggi terdapat pada akar dan kadar terendah pada tanah dalam .

Untuk mengetahui adanya perbedaan nyata (signifikan) atau tidak signifikan pada hasil analisis di atas, dilakukan uji statistik menggunakan metode uji One Way Anava dengan batas kepercayaan $95 \%$, jika pada uji Anava terdapat perbedaan yang signifikan maka akan dilanjutkan dengan uji t.

Berdasarkan uji statistik yaitu uji anava terdapat perbedaan yang signifikan untuk masing-masing logam terhadap berbagai sampel yang diteliti, untuk logam $\mathrm{Cu}$ terdapat perbedaan yang signifikan dari berbagai sampel dengan tingkat probabilitas 0,035 atau lebih kecil dari 0,05 .Untuk logam Fe terdapat perbedaan yang signifikan dari berbagai sampel dengan tingkat probabilitas 0,001 atau lebih kecil dari 0,05 dan untuk logam Zn terdapat pula perbedaan yang signifikan dengan tingkat probabilitas 0.011 .

Kadar unsur $\mathrm{Cu}$ dan $\mathrm{Zn}$ dalam daun teh yang diperoleh apabila dibandingkan dengan data yang ada dalam lampiran Keputusan Dirjen Pengawasan Obat dan Makanan No. 03725/B/SK/VII/89, menunjukan kadar Cu dan Zn 
dalam daun teh yang diperoleh masih berasa dibawah batas yang diijinkan (kadar Cu 150,0 $\mu \mathrm{g} / \mathrm{g}$ dan $\mathrm{Zn}$ 40,0 $\mu \mathrm{g} / \mathrm{g})^{(5)}$. Sedangkan kadar Fe dalam daun teh yang diperoleh tidak dapat dibandingkan, karena tidak tercantum dalam lampiran Surat Keputusan Dirjen POM.

\section{KESIMPULAN}

Berdasarkan hasil penelitian yang diperoleh dapat disimpulkan bahwa :

1. Dalam sampel tanah dalam, tanah luar, daun teh dan minuman yang masing-masing berasal dari daerah kecamatan Keparakan, Temanggung, Jawa Tengah,terdapat $\mathrm{Cu}$, Fe dan $\mathrm{Zn}$.

2. Kadar Cu dan Zn di dalam sampel daun teh tidak melebihi batas baku mutu yang ditetapkan oleh Dirjen POM.

\section{DAFTAR PUSTAKA}

1. ANONIM., Analisis Air dan Pencemaran Ligkungan, Pusarpedal Bipedal Jakarta, (1997).

2. CORNELLLJ and DOULT JD., Kimia dan Ekotoksikologi Pencemaran, UI Pers, Jakarta, (1995).

3. DARMONO, Logam dalam Sistem Biologi MahlukHidup, UI Pers, Jakarta, (1995).

4. FERDIAZ., Polusi Air dan Udara, Kanisius, Jakarta, (2000).

5. ANONIM., Keputusan Direktur Jenderal Pengawasan Obat dan Makanan No. 03725/B/SK/VII/89 Tentang Batas Maksimum Cemaran Logam Dalam Makanan. 